\title{
Microdochium bolleyi, a common inhabitant of barley and wheat roots in Finland
}

\author{
ASKO HANNUKKALA and HILKKA KOPONEN
}

\begin{abstract}
HANNUKKALA, A. \& KOPONEN, H. 1988: Microdochium bolleyi, a common inhabitant of barley and wheat roots in Finland. - Karstenia 27: 31-36.

Studies on the occurrence of pathogenic root-infecting fungi in different crop sequences in South Finland revealed Microdochium bolleyi (Sprague) de Hoog \& HermanidesNijhof on roots and stem bases of barley and wheat. The fungus was usually isolated together with the major pathogens Gaeumannomyces graminis (Sacc.) v. Arx \& Oliver, Bipolaris sorokiniana (Sacc.) Shoem. and Fusarium species. The cultural and morphological characteristics of the isolates examined agreed well with the original description of $M$. bolleyi. The fungus was most prevalent on mature cereal roots. Roots of barley and wheat were more often inhabited by $M$. bolleyi than those of oats or non-graminaceous plants. In crop sequences barley increased, but oats decreased the number of roots invaded by $M$. bolleyi.
\end{abstract}

Asko Hannukkala, Department of Plant Pathology, University of Helsinki, SF-00710 Helsinki, Finland (Present address: Institute of Plant Pathology, Agricultural Research Centre, SF-31600 Jokioinen, Finland)

Hilkka Koponen, Department of Plant Pathology, University of Helsinki, SF-00710 Helsinki, Finland

\section{Introduction}

Microdochium bolleyi (Sprague) de Hoog \& Hermanides-Nijhof is a common inhabitant of the roots of several grasses, including barley, wheat and oats (Sprague 1948, Sharp 1959, Hoes 1962). It has frequently been isolated from a wide range of soil types (Domsch et al. 1980), but in spite of its obviously widespread occurrence, the fungus has received little attention. This is probably due to its polymorphic nature and to difficulties in its identification (de Hoog \& Hermanides-Nijhof 1977, Domsch et al. 1980).

$M$. bolleyi can be isolated from roots of wheat and barley throughout the growing season (Sharp 1959, Murray \& Gadd 1981), though it is particularly abundant on the juvenile and very old parts of the root system (Hoes 1962). M. bolley is considered to be a weak pathogen of cereals and grasses (Sprague 1950, Sharp 1959, Fitt \& Hornby 1978). It is a specialised necrotrophic parasite of graminaceous hosts, but is normally confined to the root cortex (Salt 1979). It can frequently be isolated from roots showing brown lesions, but hyphae and chlamydospores of the fungus can be found in the root cells of evidently healthy roots (Stetter \& Leroul 1979). In laboratory tests the fungus has caused root injuries to such nongraminaceous hosts as alfalfa and pea (Domsch \& Gams 1968). Inoculation of wheat stems with the fungus has protected the stems from attack by pathogenic Fusarium species (Reinecke et al. 1979).

Crop sequence has been reported to have a clear effect on the prevalence of $M$. bolleyi. Cultivation of wheat and barley may increase the percentage of the fungus in the fungal population of the soil (Domsch et al. 1968). Isolates from fields kept continuously under barley have proved to be more pathogenic to barley than isolates from fields under first-year barley (Stetter \& Leroul 1979). The present study is apparently the first report on the occurrence of $M$. bolleyi in Finland. 


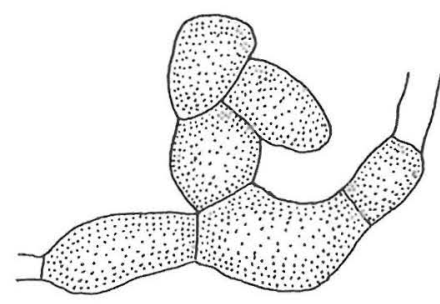

C

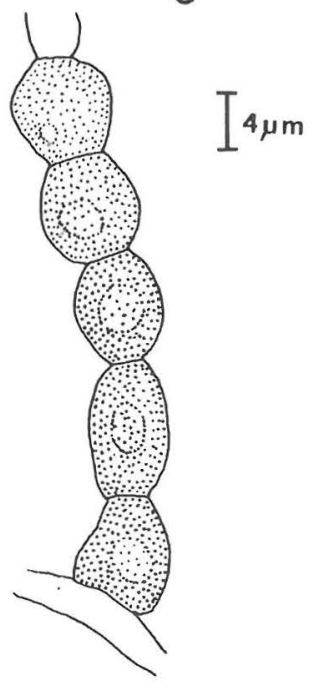

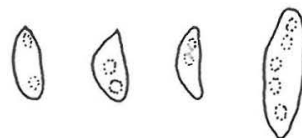

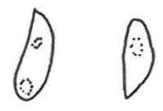

3
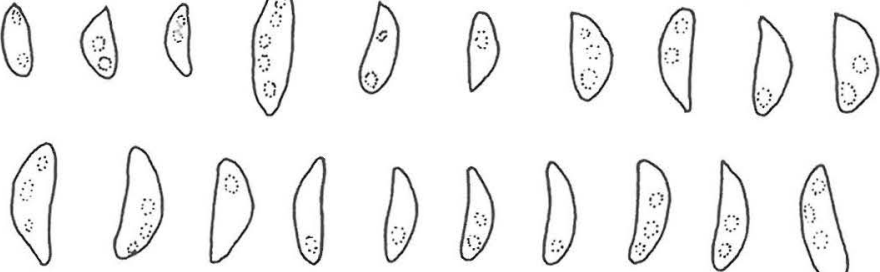
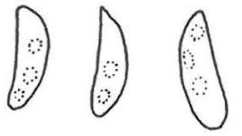
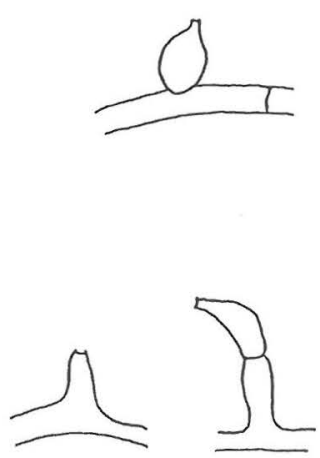

a
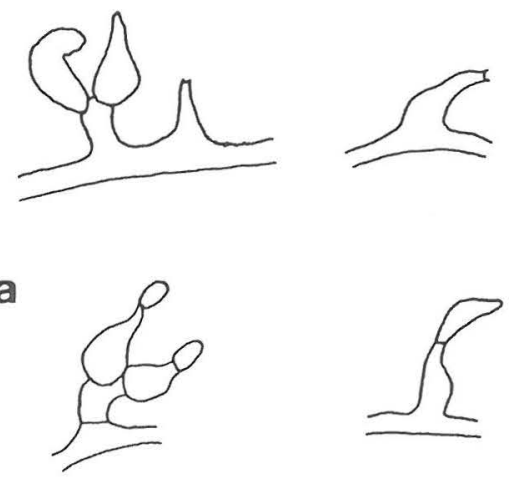

Fig. 1. Microdochium bolleyi. a) conidiogenous structures, b) conidia, c) chlamydospores. Strain no. 166.

\section{Materials and methods}

Studies on the occurrence of root rots and pathogenic root-infecting fungi in different crop sequences have been carried out at the Department of Plant Pathology of the University of Helsinki since 1977. These revealed Microdochium bolleyi (Sprague) de Hoog \& Hermanides-Nijhof in some of the root samples examined and systematic observations on the occurrence of $M$. bolleyi were started in 1982 . However, the isolation techniques used were designed to yield major pathogens, such as Fusarium avenaceum (Fr.) Sacc., F. culmorum (W.G. Sm.) Sacc., Gaeumannomyces graminis (Sacc.) v. Arx \& Oliver and Bipolaris sorokiniana (Sacc.) Shoem.

Root and stem samples were obtained for study in 1982-1985 from field tests at the experimental farms of the University of Helsinki in Helsinki and in Siuntio, $80 \mathrm{~km}$ west of Helsinki. The samples origi- nated from 12 different crop sequences at Helsinki and 8 crop sequences at Siuntio. Crop sequences in which barley and wheat were grown at 2-4-year intervals, with oats, turnip rape and faba bean as break crops, were compared with barley and wheat monocultures. The soil type in all the experiments was heavy clay. Commercial fertilizer (NPK 15-2015) was used at the rate of $600 \mathrm{~kg} / \mathrm{ha}$ in all the sequences, except four at Siuntio, which received organic compost or farm-yard manure.

A randomized sample of 200-1000 plants was taken yearly from each crop sequence at growth stages 2, 10.3 and 10.5 (Feekes-Large scale) for disease rating. In additon, soil samples from the 12 sequences at Helsinki were taken after the harvest in 1982 and 1983. The soil samples were kept at a temperature of $+5^{\circ} \mathrm{C}$ and tested in the greenhouse during winter. Four plastic pots (3 litres each) were filled 


\section{Microdochium bolleyi on roots of barley and wheat}

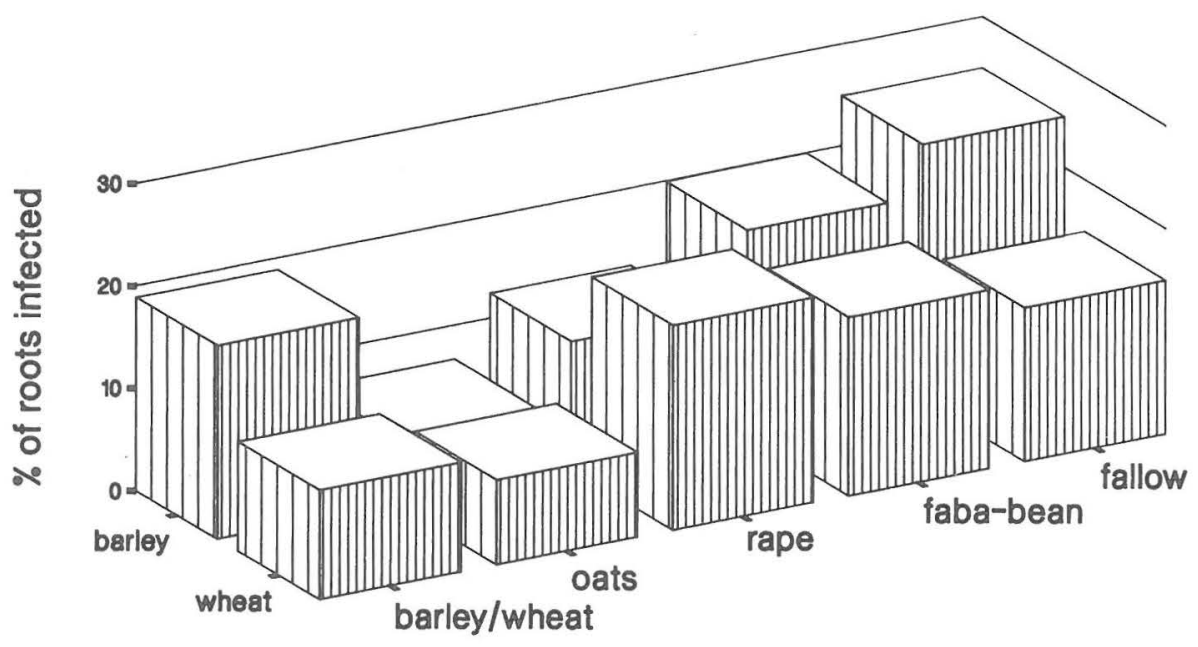

crop

pre-crop

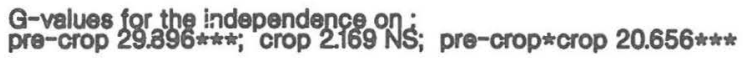

Fig. 2. The occurrence of Microdochium bolleyi on roots of barley and wheat grown in different crop sequences in field experiments in 1982-1985. In sequences where barley/wheat is a pre-crop, barley precedes barley and wheat precedes wheat.

with soil originating from each crop sequence. Thirty barley seeds were sown in the greenhouse at a temperature of $+20^{\circ} \mathrm{C}$. At growth stage 10.1 (FeekesLarge scale), the plants were removed for disease rating.

Fungi on diseased stem bases and roots of field and greenhouse samples were isolated and identified by the methods described by Stetter and Leroul (1979). For primary isolation CMA (Corn meal agar, Difco) was used instead of PDA (Potato dextrose agar, Difco). In 1984 and 1985 several selective media for isolating root-infecting fungi were used. The results included in the study were obtained from a total number of 12642 root and stem pieces analysed by isolation techniques yielding considerable amounts of $M$. bolleyi.

The growth rate, pigmentation and morphological characteristics of $M$. bolleyi were studied on pure cultures grown on PDA at room temperature $\left(+22^{\circ} \mathrm{C}\right)$ for 3-15 days. The fungal structures were examined directly on the agar plates by covering the edge of the colony with a cover glass. The spore size was mea- sured with an ocular micrometer from a spore suspension made in lactophenol-trypan blue solution from 14-day-old cultures.

Experimental data consisting of the counts of $M$. bolleyi were analysed with the G-text for independence (Sokal \& Rohlf 1969). The significance of the frequencies not dependent on the test factor is indicated in the text with $*, * *, * * *$ for risk levels of $0.5 \%, 0.1 \%, 0.01 \%$, respectively. In the text and tables the prevalence of $M$. bolleyi is expressed as percentages of the roots or stem bases examined.

\section{Results and discussion}

Isolates of Microdochium bolleyi grew very slowly on PDA. The growth rate (diameter of the colony) was $5.6-7.1(-8.4) \mathrm{cm}$ in 13 days at room temperature. At first the isolates were pink in colour, due to the production of yeasty masses of conidia. Later the cultures became dark brown or black, smooth or wrinkled. The growth zone was pink and irregular. 


\section{Microdochium bolleyi \\ on roots and stem bases of barley}

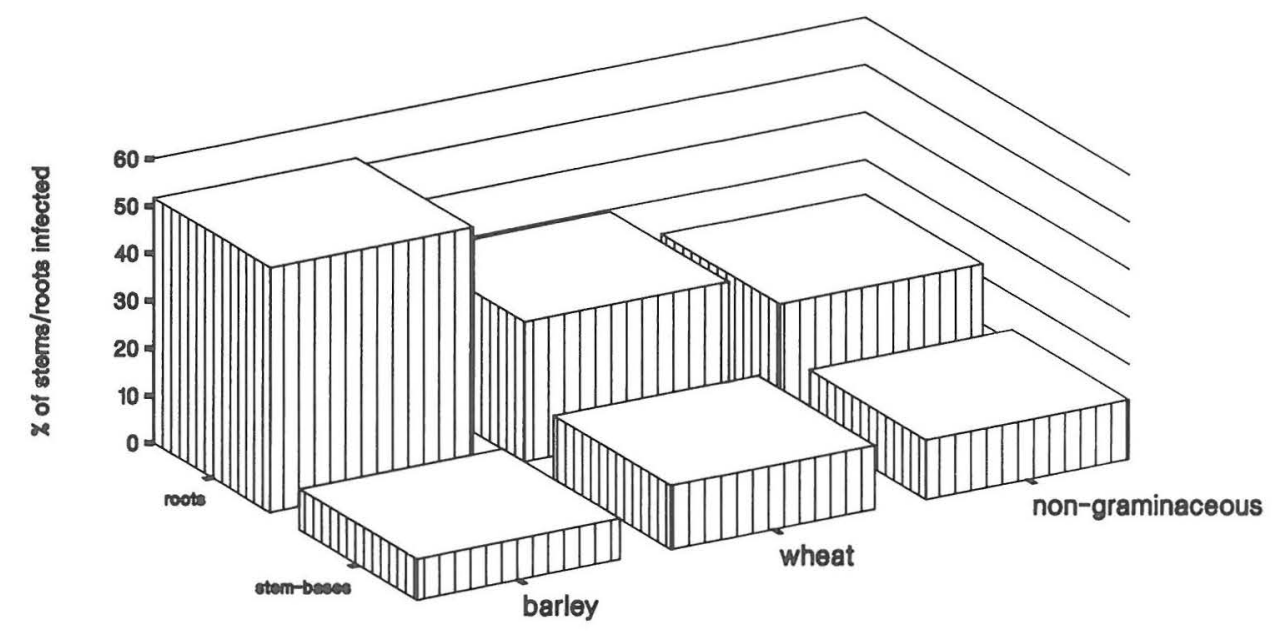

pre-crop

\section{Q-valueg for the independence 80 pre-crop:
roots $13.074 \div$ stem bases 1.008 Ts}

Fig. 3. The occurrence of Microdochium bolleyi on roots and stem bases of barley grown in soils originating from different crop sequences.

The aerial mycelium was very scanty or totally absent, cream or greyish in colour. The reverse side was first pink, later black.

Conidiogenous cells were hyaline, cylindrical, globose or subglobose, acuminate. A curved rachis often developed (Fig. 1a). The conidia developed either directly on hyphae or on side branches composed of 1-2 globose cells. The conidia were hyaline, lunate, one-celled (Fig. 1b), smooth, 5.6$6.8 \times 1.6 \mu \mathrm{m}$. Young conidia were non-guttulate, but they soon became 1-3-guttulate. Brown chlamydospores developed abundantly in chains or clusters (Fig. 1c). The cultural and morphological characteristics agree well with the description of Microdochium bolleyi (de Hoog \& Hermanides-Nijhof 1977).

$M$. bolleyi grew fairly vigorously from roots and stem bases placed on CMA. The fungus produced typical slimy, pink or orange masses of conidia and black or brown clusters of conidia with 5-10 days, which enabled the identification of $M$. bolleyi directly on primary isolation plates. $M$. bolleyi competed well with other root-inhabiting fungi on CMA. In the presence of fast growing Fusarium species, M. bolleyi remained detectable at about $1 \mathrm{~cm}$ distance from the root. On PDA, which is often recommended for isolating root-rot fungi (Stetter \& Leroul 1979, Domsch et al. 1980), it was not possible to detect $M$. bolleyi if species of Fusarium were present. A selective medium for isolating Gaeumannomyces graminis (Junke et al. 1984) gave about the same counts of $M$. bolleyi as CMA.

M. bolleyi is a common inhabitant of roots of cereals. It was found on at most $12.6 \%, 11.0 \%$ and $4.5 \%$ of the roots of barley, wheat and oats, respectively. It was also frequently isolated from stem bases of barley and wheat, but not from oats, turnip rape or faba bean (Table 1). The yearly variation in the occurrence of $M$. bolleyi was considerable.

The growth stage of barley and wheat had a clear effect on the occurrence of $M$. bolleyi. At growth stage 2 , very few roots were inhabited by the fungus, while after growth stage 10.3 , about $10 \%$ of the roots were infected (Table 2). This indicates that $M$. bolleyi is a secondary invader of roots. Juvenile tissues, e.g. 
Table 1. The occurrence of Microdochium bolleyi on stem base and root samples from field crops in 19821985.

\begin{tabular}{lcccc}
\hline Crop & $\begin{array}{l}\text { Stem bases } \\
\text { \% of stems } \\
\text { invaded by } \\
\text { M. bolleyi }\end{array}$ & $\begin{array}{l}\text { Number of } \\
\text { stems } \\
\text { examined }\end{array}$ & $\begin{array}{l}\text { Roots } \\
\% \text { of roots } \\
\text { invaded by } \\
\text { M. bolleyi }\end{array}$ & \begin{tabular}{l}
$\begin{array}{l}\text { Number of } \\
\text { roots } \\
\text { examined }\end{array}$ \\
\hline Barley, two-rowed
\end{tabular} \\
$\begin{array}{l}\text { Barley, six-rowed } \\
\text { Spring wheat }\end{array}$ & 1.3 & 1504 & 9.9 & 2695 \\
Winter wheat & 2.3 & 1521 & 12.6 & 1680 \\
Oats & 0.7 & 148 & 8.4 & 2760 \\
Turnip rape & 0 & 240 & 11.0 & 625 \\
Faba bean & 0 & 135 & -5 & - \\
\hline
\end{tabular}

Table 2. Effect of growth stage (Feekes-Large scale) of barley and wheat on the prevalence of Microdochium bolleyi on roots in 1982-1985.

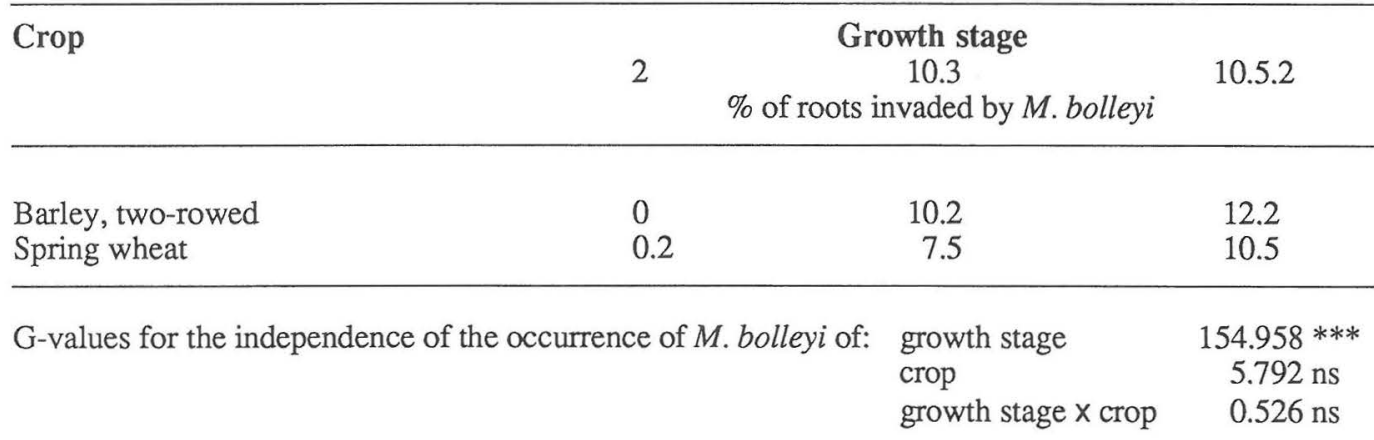

root tips, where abundant occurrence of the fungus has been reported (Hoes 1962), were not studied.

All roots and stem bases examined showed symptoms of disease. Together with $M$. bolleyi, the samples normally yielded $F$. culmorum, other Fusarium species, Gaeumannomyces graminis or Bipolaris sorokiniana. Numerous diseased roots were also found where $M$. bolleyi was the only fungus isolated, but this may merely indicate unsuitability of the methods for isolating major pathogens which are poor competitors, such as $G$. graminis.

The prevalence of $M$. bolleyi on barley and wheat roots varied considerably between crop sequences. In the field experiments, oats at the preceding crop gave the lowest counts of $M$. bolleyi. Barley, non-graminaceous crops and fallow gave high counts of $M$. bolleyi, while the percentage of infected wheat roots was low after wheat (Fig. 2).

In the pot experiments, $M$. bolleyi was more prevalent than in the field. The cropping history of the soils tested had no effect on the occurrence of $M$. bolleyi on the stem bases of barley. When barley was grown after barley, over 50\% of the roots were inhabited by $M$. bolleyi. The percentage was much smaller after wheat. Non-graminaceous pre-crops gave about the same counts of $M$. bolleyi in both the field and greenhouse (Fig. 3).

Barley is reported to increase the number of $M$. bolleyi in the soil (Domsch et al. 1968, Stetter \& Leroul 1979), which was also evident in the present study. The low counts of $M$. bolleyi after wheat and relatively high counts after non-graminaceous crops or fallow are not in full agreement with results of Domsch et al. (1968). 
Acknowledgements. We are greatly indebted to Mrs Pirkko Korhonen for technical assistance and to Mrs Anna A. Damström, M.A., for revising the English of this paper.

\section{References}

Domsch, K.H. \& Gams, W. 1968: Die Bedeutung vorfruchtabhängiger Verschiebungen in der Bodenmikroflora. - Phytopathol. Z. 63: 64-73.

Domsch, K.H., Gams, W. \& Weber, E. 1968: Der Einfluss verschiedener Vorfrüchte auf das Bodenpilzspektrum in Weizenfeldern. - Z. Pflanzenernähr. Bodenkunde 119: 134-149.

Domsch, K.H., Gams, W. \& Anderson, T.-H. 1980. Compendium of soil fungi 1. $-859 \mathrm{pp}$. London.

Fitt, B.D.L. \& Hornby, D. 1978: Effect of root infecting fungi on wheat transport processes and growth. Physiol. Plant Pathol. 13: 335-346.

Hoes, J.A. 1962: Dynamics of the mycoflora of subterranean parts of winter wheat in the dryland area of Washington. Phytopathol. 52: 736.

de Hoog, G.S. \& Hermanides-Nijhof, E.J. 1977: Survey of the black yeasts and allied fungi. - Stud. Mycol. 15: 178-221.

Junke, M.E., Mathre, D.E. \& Sands, D.C. 1984: A selective medium for Gaeumannomyces graminis var. tritici. - Plant Dis. 68: 233-236.

Murray, D.I.L. \& Gadd, G.M. 1981: Preliminary studies on Microdochium bolleyi with special reference to colonization of barley. - Trans. British Mycol. Soc. 76: 397-403.

Reinecke, P., Duben, J. \& Fehrmann, H. 1979: Antagonism between fungi of the foot rot complex of cereals. - In: Schippers, B. \& Gams, W. (eds.), Soil-borne plant pathogens: 327-336. London.

Salt, G.A. 1979: Increasing interest in minor pathogens. In: Schippers, B. \& Gams, W. (eds.), Soil-bome plant pathogens: 289-312. London.

Sharp, E.L. 1959: Two previously unreported fungi on cereals in Montana. - Plant Dis. Rep. 43: 12-13.

Sokal, R.R. \& Rohlf, F.J. 1969: Biometry. The principles and practice of statistics in biological research. 776 pp. San Francisco.

Sprague, R. 1948: Gloeosporium decay in Gramineae. Phytopathol. 38: 131-136.

- 1950: Diseases of cereals and grasses in North America. $538 \mathrm{pp}$. New York.

Stetter, S. \& Leroul, N. 1979: Ensidig bygdyrkning 2. Indflydelsen på røddernes svampeflora. - Tidsskr. Planteavl. 83: 50-72.

Accepted for publication

on 5 November 1986 